\title{
Successful management of late coronary aneurysm after bare metal stent implantation:
}

\section{An insidious threat}

Çıplak metal stent implantasyonu sonrası geç koroner arter anevrizmasının başarılı yönetimi: Bir sinsi bir düşman

\section{Emre Özdemir ${ }^{1}$}

\begin{abstract}
Development of coronary arterial aneurysm (CAA) is a rare complication after stent implantation, and even more uncommon after bare metal stents (BMS) compared with drug eluting stents. The case is here presented of a 55year-old male with in-stent CAA, which developed 9 months after BMS implantation. The patient was treated with percutaneous re-implantation of BMS and at the clinical follow-up examination, 10 months after this treatment, there were no problems on the coronary angiography and the patient had no complaints. The treatment strategy is not clear for CAAs, so it must be decided after consultation between the cardiologist and cardiac surgeon. BMS re-implantation can be a successful treatment.
\end{abstract}

Key words: bare metal stent, coronary aneurysm, coronary stent, percutaneous coronary intervention
${ }^{1}$ Katip Celebi University, Ataturk Education and Research Hospital, Cardiology Clinic, Izmir, Turkey.

Informed Consent: The written consent was received from the patient who was presented in this study.

Hasta Onamı: Çalışmada sunulan hastadan yazılı onam alınmıştır.

Conflict of Interest: No conflict of interest was declared by the authors.

Çıkar Çatı̧̧ması: Yazarlar çıkar çatışması bildirmemişlerdir.

Financial Disclosure: The authors declared that this case has received no financial support. Finansal Destek: Yazarlar bu olgu için finansal destek almadıklarını beyan etmişlerdir.

Geliş Tarihi / Received: 06.11.2018

Kabul Tarihi / Accepted: 06.03.2019

Yayın Tarihi / Published: 15.03.2019

Öz

Koroner arter anevrizmaları (KAA) gelişimi, stent implantasyonu sonrası nadir görülen bir komplikasyondur, özellikle de ilaç salınımlı stentlerle karşılaştırıldığında çıplak metal stentlerden (ÇMS) sonra çok nadir görülür. 55 yaşında bir hastanın ÇMS implantasyonundan 9 aylık bir süre sonra gelişen in-stent KAA ait bir vaka sunulmuştur. Bu KAA perkütan olarak tedavi edilmiş olup, bu tedaviden 10 ay sonra yapılan kontrol koroner anjiyografi ve klinik takiplerde her hangi bir sorun ya da şikayet kalmadığı görülmüştür. KAA için tedavi yöntemi net değildir; bu nedenle kardiyolog ve kalp cerrahı arasındaki konsültasyondan sonra kararlaştırılmalıdır. ÇMS' in yeniden implantasyonu başarılı bir tedavi yöntemi olabilir.

Anahtar Kelimeler: çıplak metal stent, koroner anevrizma, koroner stent, perkütan koroner girişim
Sorumlu yazar / Corresponding author Emre Ozdemir

Adres/Address: Izmir Katip Celebi University Ataturk Education and Research Hospital, Cardiology, Basin Sitesi/Karabaglar-Izmir, Turkey, Post Code: 35360 .

e-mail: emreozdemir27@yahoo.com.tr Tel/Phone: +90 (232) 2444444

Copyright $\odot$ ACEM 


\section{Introduction}

Coronary arterial aneurysms (CAAs) are defined as dilatation of the coronary artery exceeding $50 \%$ of the reference vessel diameter [1] The known incidence of CAAs is $0.3 \%-5.3 \%$ with angiography and $1.4 \%$ with autopsy [2]. The incidence of CAAs after percutaneous transluminal coronary angioplasty is approximately $5 \%$ [3].

Drug-eluting stent (DES) implantation is associated with altered vascular healing and delayed endothelialization due to inhibition of intimal healing [4]. This is the main reason for $\sim 1 \%$ risk of CAAs after DES implantation [4]. CAAs may also develop after bare metal stent (BMS) implantation due to wallstretching, stent fracture and intimal-dissection [5].

Other reasons for aneurysm development include Kawasaki disease, polyarteritis nodosa, systemic lupus erythematosus, infection, traumatic injury, endocarditis, rheumatic fever, and congenital malformation and de novo atherosclerosis [6].

The case is here presented of a patient who developed CAA within 9 months of BMS implantation in the left anterior descending (LAD) artery applied as primary coronary intervention for an acute anterior myocardial infarction.

\section{Case report}

A 55-year-old male patient with no comorbid disease was admitted to the Emergency Department(ED) with chest pain. Acute anterior myocardial infarction was detected on ECG. Coronary angiography (CAG) revealed a lesion with 99\% thrombosis in the proximal LAD, circumflex artery $(\mathrm{Cx})$ plaque, optus marginalis (OM) $80 \%$ stenosis (diameter $<2 \mathrm{~mm}$ ) and a $70 \%$ mid lesion in the right coronary artery (RCA). The LAD lesion was treated with a 4.5 x $24 \mathrm{~mm}$ Ephesus BMS (Alvimedica, Istanbul, Turkey) after $2.0 \times 20 \mathrm{~mm}$ balloon predilation during primary percutaneous coronary intervention (PCI) (Figure-1a, b, c). When left ventricular ejection fraction (LVEF) was detected as $50 \%$, the patient was discharged successfully after clinical follow-up with medical treatment included acetylsalicylic acid, clopidogrel, metoprolol and statin.

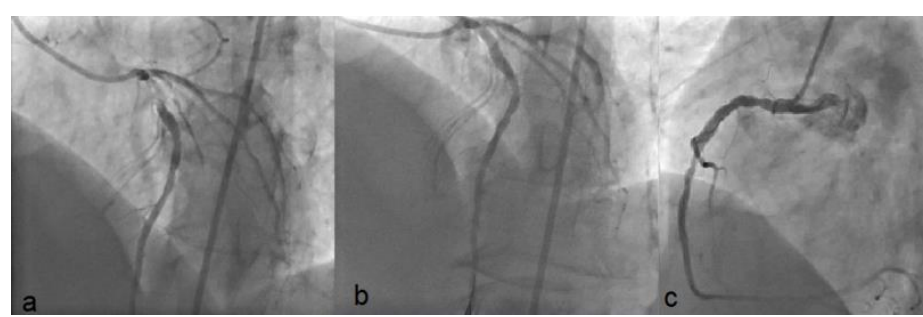

Figure 1. a, b, c : (a) $99 \%$ thrombosed lesion at the proximal LAD, (b) successful implantation of BMS in the LAD lesion, (c) $70 \%$ thrombosed lesion at the middle of $\mathrm{RCA}(\mathrm{c})$.

At approximately one month after the primary PCI, the patient was re-admitted to ED with recently developed chest pain. CAG was performed, and the LAD stent was observed to be patent but PCI was applied again to the RCA mid 70\% lesion with direct implantation of a 3.5x15 Ephesus BMS (Alvimedica, Istanbul, Turkey) (Figure-2a, b).

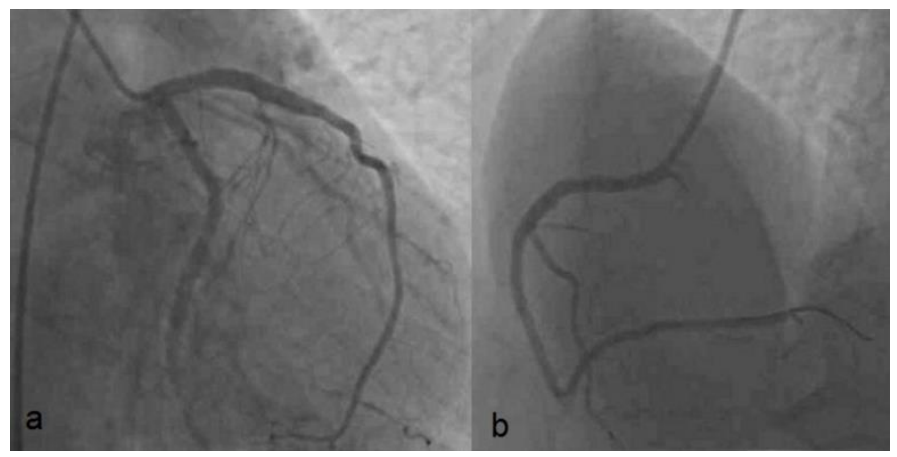

Figure 2. a, b: (a) Patent LAD stent without aneurysm, (b) Image of RCA after BMS implantation.

During follow-up, anterior-wall myocardial ischemia was detected on myocardial perfusion scintigraphy (MPS) at 8 months after the RCA PCI. CAG was applied again, which revealed a LAD in-stent $90 \%$ lesion and in-stent coronary aneurysm after the lesion, but the RCA stent was patent and there was non-obstructive plaque in $\mathrm{Cx}$. Intravascular ultrasound (IVUS) or optical coherence tomography (OCT) could not be applied. Therefore, the treatment strategy had to be decided only based on the CAG findings. Following an in-clinic consultation, it was decided to continue with PCI. Pre-dilatation was performed with a 4.0 x $16 \mathrm{~mm}$ balloon and a $4.5 \times 20 \mathrm{~mm}$ Liberte BMS (Boston Scientific, MA, USA) was then implanted in the stent, to close the in-stent aneurysmal segment. There was no significant residual aneurysm or occlusion on CAG after PCI. The patient was discharged successfully one day after PCI. Clopidogrel treatment was changed to ticagrelor.

At the follow-up examination 10 months after this procedure, no symptoms were observed on CAG. There was no aneurysm on the LAD stent position, the RCA stent was patent but LAD in-stent re-stenosis $(50 \%)$ was detected but was confirmed as non-critical via fractional flow reserve measurement (Figure-3a, b, c). At the 2-month clinical follow-up examination after the last $\mathrm{CAG}$, the patient had no complaints. The left ventricular ejection fraction was still $55 \%$ and he continued to take acetylsalicylic acid, ticagrelor, metoprolol and statin.

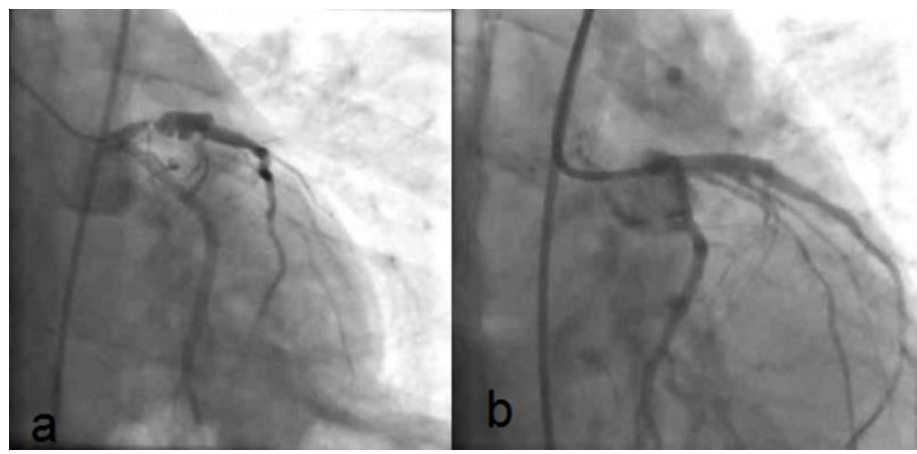

Figure 3. a, b, c: (a) newly- developed in-stent CAA on LAD and instent critical restenosis, (b) CAA successfully treated with a new BMS implantation in the old stent to cover the aneurysm, (c) no aneurysm on the final follow-up CAG.

Written informed consent was obtained from the patient for all procedures.

\section{Discussion}

CAAs can be asymptomatic or may be complicated by angina pectoris, myocardial infarction or sudden death [7]. CAAs can be classified in three pathological groups: atherosclerotic, inflammatory, and non-inflammatory. Non-inflammatory CAAs 
also include iatrogenic aneurysms. These iatrogenic aneurysms can be associated with injuries of the vessel wall with a focal tear secondary to intravascular intervention [8].

CAA due to DES implantation is a rare complication, seen in approximately $1 \%$ of cases [9]. Interventional procedures, hypersensitivity reactions associated with the stent platform (metal), drug carrier polymer, DES drugs or infectious (mycotic) processes are the factors responsible for the development of CAAs after DES implantation [4]. Coronary dissection, stent fracture associated with high-pressure balloon inflation or coronary atherectomy, may also lead to the development of CAA after BMS implantation [11]. Furthermore, a hypersensitive reaction to molybdenum, nickel and chromium has been reported in $\sim 10 \%$ of the patients with BMS implantation [12].

CAAs due to stent implantation can be categorized as three types. Type I develops in the first 4 weeks after PCI, and Type II develops more than 6 months after PCI. These two types can be asymptomatic or can present with angina. Type III is associated with superinfection (mycotic aneurysm), and may present with systemic signs such as fever [4].

The current patient had non-specific symptoms, so was applied with CAG after evaluation with MPS. In this case, there was in-stent CAA at approximately 9 months after BMS implantation, but at 1 months after LAD PCI a control CAG was performed and the LAD stent was patent and there was no aneurysm at that time. Therefore, this case can be classified as Type-II CAA.

There are no documented guidelines for the management of post-stent CAAs. The optimal management method remains unclear due to conflicting data from individual case reports. Treatment strategies can be classified as medical therapy including antiplatelet or anticoagulant therapy [13], PCI therapy encompassing stent implantation, coil embolization, and BMS implantation [14-15] or surgical therapy [16].

Previous reports include the presentation by Yasuaki Hada et al. [14] of CAA that developed after DES implantation and was treated successfully with BMS, and Ioannis Iakovou et al. [15] presented 3 CAA cases successfully treated with BMS.

In accordance with this information, it was decided, after consultation, to treat the current patient with BMS implantation therapy instead of covered stent or surgery. After pre-dilatation with a $4.0 \times 16 \mathrm{~mm}$ balloon, a $4.5 \times 20 \mathrm{~mm}$ Liberty BMS was successfully implanted into the old-stent, to close the in-stent aneurysmal segment. The patient was thus successfully treated with PCI. Clopidogrel treatment was changed to ticagrelor. The patient was discharged with high-dose statin (atorvastatin $80 \mathrm{mg}$ ) + acetylsalicylic acid + ticagrelor + metoprolol regime. Ten months later, follow-up CAG and LAD FFR showed no aneurysm or critical lesion in the LAD stent. The patient has remained free of complaints with clinical follow-up visits.

We didn't use advanced techniques like, intravascular ultrasound or optical coherence tomography, so we couldn't explain the etiology. This issue can be regarded as the main limitation of the paper. However, treatment of in-stent aneurysm with a simple and inexpensive method is the strength of the case.

The case was here reported of a patient with CAA 9 months after BMS implantation, which developed in a 1-month period. A hypersensitivity reaction against the BMS metal, stent fracture or dissection under the stent due to over-dilatation can be reasons for CAA after BMS implantation. Due to problems with reimbursement agency payments, intravascular ultrasound or optical coherence tomography could not be applied. Therefore, the treatment strategy had to be decided only based on the CAG findings. The use of intravascular ultrasound can prevent over-dilation of the stent and/or the selection of an oversized stent, thereby avoiding stretching of the coronary wall. The treatment strategy must be decided after consultation between the cardiologist and the cardiac surgeon and BMS re-implantation can be a successful treatment.

\section{References}

1. Syed M, Lesch M. Coronary artery aneurysm: a review. Prog Cardiovasc Dis. 1997; 40:77-84

2. Warisawa T, Naganuma T, Tomizawa N, Fujino Y, Ishiguro H, Tahara $\mathrm{S}$, et al. High prevalence of coronary artery events and non-coronary events in patients with coronary artery aneurysm in the observational group. Int J Cardiol Heart Vasc. 2016;10: 29-31

3. Bal ET, Plokker HWT, Van de Berg EMJ, Ernst SMPG, Mast EG, Gin RMTJ, et al. Predictability and prognosis of PTCA-induced coronary artery aneurysms. Cathet Cardiovasc Diagn. 1991;22:85-8.

4. Aoki J, Kirtane A, Leon MB, Dangas G. Coronary artery aneurysm after drug-eluting stent implantation. J Am Coll Cardiol Intv. 2008;1:14-21.

5. Nichols L, Lagana S, Parwani A: Coronary artery aneurysm: A review and hypothesis regarding etiology. Arch Pathol Lab Med. 2008;132:823-8.

6. Chrissoheris MP, Donohue TJ, Young RS, Ghantous A. Coronary artery aneurysms. Cardiology in review. 2008;16:116-23.

7. Pappy R, Wayangankar S, Kalapura T, Abu-Fadel MS. Rapidly evolving coronary aneurysm in a patient with rheumatoid arthritis. Cardiol Res Pract. 2011;2011:659439.

8. Cabarrus M, Yang B, Schiller N, Miller DC, Ordovas K. Iatrogenic giant coronary artery pseudoaneurysm with "daughter aneurysm" formation: serial imaging findings and natural history. J Thorac Imaging. 2012;27:185-7.

9. Ahn CM, Hong BK, Kim JY, Min PK, Yoon YW, Lee BK, et al Incidence and natural history of coronary artery aneurysm developing after drug-eluting stent implantation. Am Heart J. 2010;160:987-94.

10. Nonin S, Hasegawa T, Hirai H, Suehiro S, Yoshiyama M. Gi $\neg$ ant mycotic coronary aneurysm associated with late stent infection. Eur Heart J Cardiovasc Imaging. 2014;15: 630.

11. Crawley PD, Mahlow WJ, Huntsinger DR, Afiniwala S,Wortham DC. Giant coronary artery aneurysms: Review and update. Tex Heart Inst J. 2014;41:603-8 .

12. Köster R, Vieluf D, Kiehn M, Sommerauer M, Kähler J, Baldus S. et al. Nickel and molybdenum contact allergies in patients with coronary instent restenosis. Lancet. 2010;356:1895-7.

13. LaMotte LC, Mathur VS. Atherosclerotic coronary artery aneurysms: 8year angiographic follow-up. Tex Heart Inst J. 2000;27: 72-3.

14. Hada Y, Fujii H, Shimizu M, Yamawake N, Nishizaki M. Effectiveness of Bare Metal Stent Implantation for the Treatment of Coronary Artery Aneurysm: A Multimodality Imaging Evaluation. Intern Med. 2017;56:3305-9.

15. Iakovou I, Dimopoulos A, Dangas G. Normal to normal: a method of treatment of coronary aneurysms with deployment of bare-metal stents. J Invasive Cardiol. 2011;23:121-5.

16. Ghanta RK, Subroto Paul, Gregory SC. Successful revascularization of multiple coronary artery aneurysms using a combination of surgical strategies. Ann Thorac Surg. 2007;84:10-1. 